\title{
Effect of Crop Rotation and Cereal Monoculture on the Yield and Quality of Winter Wheat Grain and on Crop Infestation with Weeds and Soil Properties
}

\author{
Andrzej Woźniak ${ }^{1}$ (I)
}

Received: 10 December 2018 / Accepted: 5 March 2019 / Published online: 8 March 2019

(c) The Author(s) 2019

\begin{abstract}
An exact experiment, established in a system of randomized blocks, was aimed at determining the effect of crop rotation and 29-year cereal monoculture on the yield and quality of winter wheat grain as well as on straw yield, crop infestation with weeds, contents of organic $\mathrm{C}$ and total $\mathrm{N}$ in the soil, and the number of earthworms in the soil. Winter wheat was sown in two systems of crop succession: (1) in crop rotation (CR), and (2) in a cereal monoculture (CM). Winter wheat cultivation in the CM system resulted in a decrease of grain yield by $32 \%$, compared to the CR system. Its grain yield reduction in the $\mathrm{CM}$ system was due to a lower number of spikes $\mathrm{m}^{-2}$, lower 1000 grain weight, shorter spikes, and lower grain weight per spike, than in the CR system. Wheat grain from the CM system was characterized by a lower content of wet gluten, lesser grain uniformity and grain volume weight, and contained more total ash than the grain from the CR system. The number and air-dry weight of weeds were higher in the CM than in the CR system by $57.1 \%$ and $75 \%$, respectively. Differences were also demonstrated in the species composition of weeds. The soil samples collected from the CM plot contained less organic $\mathrm{C}$ and total $\mathrm{N}$ than the samples derived from the CR system. Soil samples from the CM system had also a lower number of earthworms compared to the CR soil samples.
\end{abstract}

Keywords Crop rotation $\cdot$ Monoculture $\cdot$ Soil properties $\cdot$ Weed infestation $\cdot$ Yield

\section{Introduction}

The yield and quality of wheat grain are determined by coeffects of habitat, agrotechnical measures as well as plant species and cultivar (Rachon et al. 2015; Schlegel et al. 2018; Woźniak and Soroka 2018). Contemporary agricultural systems usually tend to minimize expenditures incurred on tillage and make use of specialist crop rotations including 2-3 plant species requiring the same or similar cultivation technology (Soane et al. 2012; Roche et al. 2017). Sometimes, however, such solutions fail, which leads to crop productivity decrease (Haliniarz et al. 2018). Frequent cultivation of cereals one after another causes an increasing number of agrophages (weeds, pests, and fungal pathogens),

Andrzej Woźniak

andrzej.wozniak@up.lublin.pl

1 Department of Herbology and Plant Cultivation Techniques, University of Life Sciences in Lublin, Akademicka 13, Lublin, Poland which results in the necessity of using high amounts of pesticides and this, in turn, generates a significant increase in production costs (Bai and Shaner 2004; Mal et al. 2015; Mehmeti et al. 2018). Further consequences involve adverse changes in the soil including particularly decreasing contents of organic matter, organic carbon, and total nitrogen (Emmerling 2007; Cattaneo et al. 2014; Lal 2016; Woźniak and Soroka 2018). Such conditions cause also the biological and enzymatic activity of soil to diminish (Balota et al. 2004; Woźniak and Kawecka-Radomska 2016). According to Olsson and Alström (2000) and to Balota et al. (2004), this is due to little diversity of the post-harvest residues of cereals, which leads to reducing counts of saprophytic soil microorganisms. Another consequence of cereal monoculture is a decreasing number of earthworms in the soil (Woźniak and Kawecka-Radomska 2016). As reported by Laossi et al. (2004), earthworms take part in the formation of organic-mineral colloids, regulate the water-air balance in the soil, and even reduce the severity of soil-borne plant diseases (Clapperton et al. 2001). 
Wheat is a cereal species with high habitat and agrotechnical demands (Ranjbar et al. 2015). It produces higher yields after leguminous, fodder, and roots plants, whereas significantly lower ones when grown after cereals (Debaeke et al. 1996). As proved in experiments conducted by Beres et al. (2010) and by Woźniak and Soroka (2018), this is due to increased weed infestation and even to the predominance of a few weed species. According to Rasmussen et al. (2006) and Nikolich et al. (2012), weed compensation may be prevented by rotations of crops having diverse agrotechnical and biological demands. Weeds presence in wheat stand leads to undesirable changes in crop structure and, especially, to a decreased spike number and grain weight per spike, to shorter stems and spikes, and ultimately to low yields (Lund 1993). Under unfavorable agrotechnical conditions, it also contributes to a lower milling and baking value of the grain (Woźniak and Makarski 2013; Rachon et al. 2015).

This study aimed to evaluate the yield and quality of winter wheat grain, winter wheat crop infestation with weeds, and soil properties in the multi-year cereal monoculture and crop rotation systems.

\section{Materials and Methods}

\section{Experiment Location and Design}

A field experiment was established in 1988 at the Experimental Station in Uhrusk belonging to the University of Life Sciences in Lublin, south-eastern Poland $\left(51^{\circ} 18^{\prime} \mathrm{N}\right.$, $\left.23^{\circ} 36^{\prime} \mathrm{E}\right)$. Results presented in this manuscript were gathered in the year 2017 from the 29 -year cereal monoculture and crop rotation. The experiment was established in 3 replications in the system of randomized blocks having $6 \mathrm{~m} \times 25 \mathrm{~m}$ in size. Winter wheat of Skagen cultivar was sown in two systems of crop succession: (1) in crop rotation (CR): pea-winter wheat-winter triticale, and (2) in a cereal monoculture $(\mathrm{CM})$ : winter triticale-spring wheat-winter wheat.

\section{Soil and Weather Conditions}

The experiment was established on Rendzic Phaeozem (IUSS Working Group WRB 2015), which contains 24\% of silty fraction and $13 \%$ of dust fraction. The soil has slightly alkaline $\mathrm{pH}\left(\mathrm{pH}_{\mathrm{KCL}}=7.2\right)$, high contents of phosphorus $\left(132 \mathrm{mg} \mathrm{kg}^{-1} \mathrm{dm}\right)$ and potassium $\left(221 \mathrm{mg} \mathrm{kg}^{-1}\right)$, and a moderate content of magnesium $\left(75 \mathrm{mg} \mathrm{kg}^{-1}\right)$.

The study area is characterized by a relatively long growing period (i.e. the number of days with a daily air temperature over $+5^{\circ} \mathrm{C}$ ), spanning for 200-210 days. The sum of atmospheric precipitation in the years 1988/1989-2015/2016 ranged from $108 \mathrm{~mm}$ to $319 \mathrm{~mm}$ in the autumn-winter period (since November till April), and from $269 \mathrm{~mm}$ to $566 \mathrm{~mm}$ in the spring-summer period (since May till October). The coldest months in the year were January $\left(-2.2{ }^{\circ} \mathrm{C}\right.$ on average) and February $\left(-1.4{ }^{\circ} \mathrm{C}\right)$, and the warmest ones were July $\left(19.4{ }^{\circ} \mathrm{C}\right)$ and August $\left(18.4{ }^{\circ} \mathrm{C}\right)$. In the $2016 / 2017$ season, the sum of precipitation reached $172 \mathrm{~mm}$ since November till April, and $454 \mathrm{~mm}$ since May till October. In this season, the greatest precipitation was recorded in May (72 $\mathrm{mm})$ and in July $(99 \mathrm{~mm})$.

\section{Soil Tillage, Fertilization, and Plant Protection}

Ploughing tillage was applied under winter wheat grown in the $\mathrm{CR}$ and $\mathrm{CM}$ systems. It included shallow ploughing (at a depth of 10-12 cm) performed immediately after harvest of the previous crop, i.e. in the first decade of August, followed by pre-winter ploughing (at a depth of 22-25 cm) performed at the beginning of September. The following fertilizers were applied before ploughing: $20 \mathrm{~kg} \mathrm{~N} \mathrm{ha}^{-1}$, $30 \mathrm{~kg} \mathrm{Pha}^{-1}$, and $85 \mathrm{~kg} \mathrm{~K} \mathrm{ha}^{-1}$. Fertilization was calculated according soil chemical analysis. Winter wheat was sown on the 30th of September in the amount of 450 seeds $\mathrm{m}^{-2}$. In the springtime, nitrogen was administered on all plots in three terms: (1) $70 \mathrm{~kg} \mathrm{~N}^{-1}$ at the 22-33 stage in the BBCH scale, (2) $40 \mathrm{~kg} \mathrm{~N} \mathrm{ha}^{-1}$ at the $32-33 \mathrm{BBCH}$ stage, and (3) $20 \mathrm{~kg} \mathrm{~N} h a^{-1}$ at the $52 \mathrm{BBCH}$ stage (BBCH Working Group 2001). Winter wheat was protected against fungal diseases with flusilazole + carbendazim $\left(1 \mathrm{~L} \mathrm{ha}^{-1}\right)$ at the 33-34 BBCH stage and with propiconazole + fenpropidin (1 $\mathrm{L} \mathrm{ha}^{-1}$ ) at the 43-44 BBCH stage. Weed control was ensured by using MCPA + mecoprop + dicamba $\left(1.5 \mathrm{~L} \mathrm{ha}^{-1}\right)$ at the 23-24 BBCH stage.

\section{Yield Components and Statistical Analysis}

The following yield components were analyzed in the experiment: (1) grain and straw yield; (2) spike number, grain weight per spike, 1000 grain weight, spike length, and plant height; (3) contents of total protein and wet gluten in the grain, grain volume weight, grain uniformity, and total ash content; (4) number of weeds $\mathrm{m}^{-2}$, air-dry weight of weeds, species composition of weeds; (5) contents of organic $\mathrm{C}$ and total $\mathrm{N}$ in the soil; and (6) number of earthworms $\mathrm{m}^{-2}$.

Grain was harvested using a Wintersteiger plot harvester. Grain weight per spike, spike length, and plant height were evaluated at each plot based on 40 randomly collected plants, whereas spike number per $\mathrm{m}^{2}$ and 1000 grain weight were determined by measuring out $2 \times 500$ grains. Contents of total protein and wet gluten were determined with the near infrared reflectance spectroscopy (NIRS) method using an Inframatic apparatus. The grain volume weight was determined using a 1-L densitometer, and grain uniformity was established using a sorter with mesh size of 
$2.5 \mathrm{~mm} \times 25 \mathrm{~mm}$. Contents of mineral components in the grain were determined after wet mineralization of the samples at a temperature of $600{ }^{\circ} \mathrm{C}$.

Weed infestation was evaluated with the botanical-gravimetric method at the waxy maturity stage of winter wheat $(82-83 \mathrm{BBCH})$. This method consisted in determining species composition of weeds, number and air-dry weight of weeds collected from $\mathrm{m}^{2}$ of each plot. This area was marked at random (twice) using a frame $0.5 \times 1.0 \mathrm{~m}$ in size. The air-dry weight of weeds was determined by collecting all weeds from the frame area, removing their root system, and keeping them in a well-ventilated room until their constant weight has been achieved (Woźniak and Soroka 2017).

Soil samples collected from all plots were determined for the content of organic $\mathrm{C}$ with the Tiurin method and for the content of total $\mathrm{N}$ with the Kjeldahl method.

The number of earthworms (Lumbricus) per $\mathrm{m}^{2}$ was determined in the second decade of June, at the optimal soil moisture content and temperature, by manual picking of the earthworms and calculating their number in 2 soil samples collected from the surface area of $0.25 \times 1.0 \mathrm{~m}$ and depth of $0.30 \mathrm{~m}$ from each plot (Woźniak and Kawecka-Radomska 2016).

Study results were developed statistically with the method of the analysis of variance (ANOVA) using Statistica PL software. The significance of differences between mean values was determined with the $H S D$ Tukey's test at $P<0.05$.

\section{Results}

\section{Winter Wheat Grain Yield and Straw Yield and Grain Quality}

Grain and straw yield of winter wheat cultivated in the CM system was lower by $32 \%$ than of winter wheat grown in the CR system (Table 1). This decrease was due to a lower number of spikes $\mathrm{m}^{-2}$ (by $11 \%$ ), lower grain weight per spike (by $28 \%$ ), lower 1000 grain weight (by 10\%), and shorter spikes (by 13.7\%) and stems (by 6.9\%) than in the CR system (Table 2). Components of the analysis of variance ( $F$-value and $P$ ) point to significant differences between the biometric traits of wheat sown in the CM and CR systems. In addition,

Table 1 Yield of grain and straw of winter wheat

\begin{tabular}{llllll}
\hline Specification & \multicolumn{2}{l}{ Cropping system } & & \multicolumn{2}{l}{ Value } \\
\cline { 2 - 3 } \cline { 5 - 6 } & CR & CM & & $F$ & $P$ \\
\hline Grain yield $\left(\mathrm{t} \mathrm{ha}^{-1}\right)$ & 7.76 & 5.26 & & 275.4 & $* *$ \\
Straw yield $\left(\mathrm{t} \mathrm{ha}^{-1}\right)$ & 6.88 & 4.68 & & 56.1 & $* *$ \\
\hline
\end{tabular}

$C R$ crop rotation, $C M$ cereal monoculture

** $P<0.01$
Table 2 Biometric traits of winter wheat

\begin{tabular}{llllll}
\hline Specification & \multicolumn{2}{l}{ Cropping system } & & \multicolumn{2}{l}{ Value } \\
& CR & CM & & $F$ & $P$ \\
\hline Spike number $\mathrm{m}^{-2}$ & 529 & 472 & & 32.3 & $*$ \\
Grain weight per spike $(\mathrm{g})$ & 1.48 & 1.06 & & 1268.7 & $* *$ \\
1000 grain weight $(\mathrm{g})$ & 52.3 & 46.6 & & 34.9 & $* *$ \\
Spike length $(\mathrm{cm})$ & 9.30 & 8.02 & & 31.1 & $* *$ \\
Plant height $(\mathrm{cm})$ & 93.5 & 87.0 & & 21.9 & $*$ \\
\hline
\end{tabular}

$C R$ crop rotation, $C M$ cereal monoculture

$* P<0.05, * * P<0.01$

the grain yield was significantly correlated with spike number $\mathrm{m}^{-2}$, grain weight per spike, 1000 grain weight, and spike length (Table 3 ). Significant correlations were also demonstrated between spike length and grain weight per spike and between spike length and 1000 grain weight.

Winter wheat cultivation in the CM system resulted also in the lower content of wet gluten (by $4.7 \%$ points), lower grain volume weight (by $8.8 \%$ ), lesser grain uniformity (by $16 \%$ points), and a higher content of total ash in the grain (by 13.9\%) compared to the grain of winter wheat cultivated in the CR system (Table 4). Total protein content was positively correlated with wet gluten content, grain volume weight and grain uniformity, and negatively correlated with total ash content (Table 5). Significant correlations were also demonstrated between wet gluten content of the grain and grain volume weight as well as between wet gluten content in the grain and grain uniformity. In turn, the grain volume weight was positively correlated with grain uniformity and negatively correlated with total ash content.

\section{Indices of Crop Infestations with Weeds}

The number of weeds in the crop of winter wheat cultivated in the CM system was higher by $57.1 \%$ than in the CR system (Table 6). Also the air-dry weight of weeds produced in the CM system was higher by $75 \%$ than that produced on CR plots.

The most abundant weed species identified in the 29-year cereal monoculture (CM) included: Consolida regalis, Galium aparine, Apera spica-venti, and Papaver rhoeas, whereas these identified in the CR system included: Stellaria media, Polygonum aviculare, Consolida regalis, Apera spica-venti, and Veronica persica (Fig. 1).

\section{Chemical Properties of Soil and Earthworm Number}

Soil samples collected from CM plots contained less organic carbon (by $33.1 \%$ ) and total nitrogen (by 16.5\%) than the soil samples collected from the CR plots (Table 7). They 
Table 3 Coefficient of Pearson correlation between grain yield and its components

\begin{tabular}{llllll}
\hline Traits & Yield & $\begin{array}{l}\text { Spike number } \\
\mathrm{m}^{-2}\end{array}$ & $\begin{array}{l}\text { Grain weight per } \\
\text { spike }\end{array}$ & $\begin{array}{l}\text { 1000 grain } \\
\text { weight }\end{array}$ & Spike length \\
\hline Spike number $\mathrm{m}^{-2}$ & 0.73 & & & & \\
Grain weight per spike & 0.89 & 0.44 & & \\
1000 grain weight & 0.64 & 0.59 & 0.66 & 0.71 & \\
Spike length & 0.68 & 0.23 & 0.77 & 0.12 & 0.58 \\
Plant height & 0.23 & 0.19 & 0.20 & \\
\hline
\end{tabular}

Table 4 Quality parameters of winter wheat grain

\begin{tabular}{|c|c|c|c|c|}
\hline \multirow[t]{2}{*}{ Specification } & \multicolumn{2}{|c|}{ Cropping system } & \multicolumn{2}{|l|}{ Value } \\
\hline & $\mathrm{CR}$ & $\mathrm{CM}$ & $F$ & $P$ \\
\hline Total protein $\left(\mathrm{g} \mathrm{kg}^{-1} \mathrm{dm}\right)$ & 144.0 & 143.1 & 0.24 & $\mathrm{~ns}$ \\
\hline Wet gluten $(\%)$ & 32.0 & 27.3 & 40.3 & $* *$ \\
\hline Grain volume weight $\left(\mathrm{kg} \mathrm{h} \mathrm{L}^{-1}\right)$ & 81.6 & 74.4 & 105.4 & $* *$ \\
\hline Grain uniformity (\%) & 94.0 & 78.0 & 153.6 & $* *$ \\
\hline Total ash $\left(\mathrm{g} \mathrm{kg}^{-1} \mathrm{dm}\right)$ & 18.5 & 21.5 & 17.7 & $* *$ \\
\hline
\end{tabular}

$C R$ crop rotation, $C M$ cereal monoculture, $n s$ not significant $* * P<0.01$

had also a lower number of earthworms compared to the CR soil samples (by $31 \%$ ).

\section{Discussion}

The commonly applied system of crop rotation one after another for a few years has negative effects on both crop production, economy, and habitats (Haliniarz et al. 2018). These negative outcomes include mainly low grain yields and moderate grain quality (Rachon et al. 2015; Woźniak

Table 6 Number and air-dry weight of weeds in winter wheat crop

\begin{tabular}{llllll}
\hline Specification & \multicolumn{2}{l}{ Cropping system } & & \multicolumn{2}{l}{ Value } \\
\cline { 2 - 3 } & CR & CM & & $F$ & $P$ \\
\hline Number of weeds m ${ }^{-2}$ & 11.7 & 27.3 & & 14.3 & $*$ \\
Air-dry weight of weeds $\left(\mathrm{g} \mathrm{m}^{-2}\right)$ & 12.9 & 31.7 & & 27.0 & $* *$ \\
\hline
\end{tabular}

$C R$ crop rotation, $C M$ cereal monoculture

$* P<0.05, * * P<0.01$ and Makarski 2013). As claimed by many authors (Beres et al. 2010; Nikolich et al. 2012; Mehmeti et al. 2018), the low grain yield is a consequence of crop infestation by weeds and strong infestation of stems, leaves, and spikes by fungal pathogens (Clapperton et al. 2001; Bai and Shaner 2004). In the reported study, winter wheat sown in the 29-year crop monoculture $(\mathrm{CM})$ produced lower by $32 \%$ grain yield than the wheat grown in the crop rotation (CR) system. Its grain yield reduction was due to a lower number of spikes $\mathrm{m}^{-2}$, shorter spikes, lower grain weight per spike, and lower 1000 grain weight. In this system, plants were also shorter than in the CR system. This indicates explicitly that the conditions for wheat growth were less favorable in the CM than in the CR system. Similar observations were reported by Lund (1993), Debaeke et al. (1996), Soane et al. (2012), Ranjbar et al. (2015), and by Schlegel et al. (2018). Winter wheat grown in the CM system was also characterized by poorer grain quality, compared to the winter grains from the CR system, which was indicated by lower wet gluten content of the grain, lower grain volume weight and lesser grain uniformity, and by increased total ash content of the grain, compared to the CR system. According to Woźniak and Makarski (2013), a decrease in grain quality is due to the increased contribution of fine and wrinkled grain, which is produced under unfavorable cultivation conditions.

The multi-year cereal monoculture had also an adverse effect on the soil environment. The soil samples collected from the CM plots had lower contents of organic $\mathrm{C}$ (by $33.1 \%$ ), total $\mathrm{N}$ (by $16.5 \%$ ), and a lower number of earthworms (by 31\%) than these from the CR plots. Also Woźniak and Kawecka-Radomska (2016) showed that soil collected from the monoculture contained less organic $\mathrm{C}$ and less earthworms than the soil from the crop rotation. As reported by Bruyn and Kingston (1997), soil rich in diversified dry
Table 5 Coefficient of Pearson correlation between grain quality parameters

\begin{tabular}{lcccc}
\hline Traits & Total protein & Wet gluten & $\begin{array}{l}\text { Grain volume } \\
\text { weight }\end{array}$ & Grain uniformity \\
\hline Wet gluten & 0.81 & & & \\
Grain volume weight & 0.90 & 0.73 & & \\
Grain uniformity & 0.83 & 0.81 & 0.90 & \\
Total ash & -0.35 & -0.49 & -0.60 & -0.41 \\
\hline
\end{tabular}


Fig. 1 Species composition and number of weeds per $\mathrm{m}^{2}$ in winter wheat crop

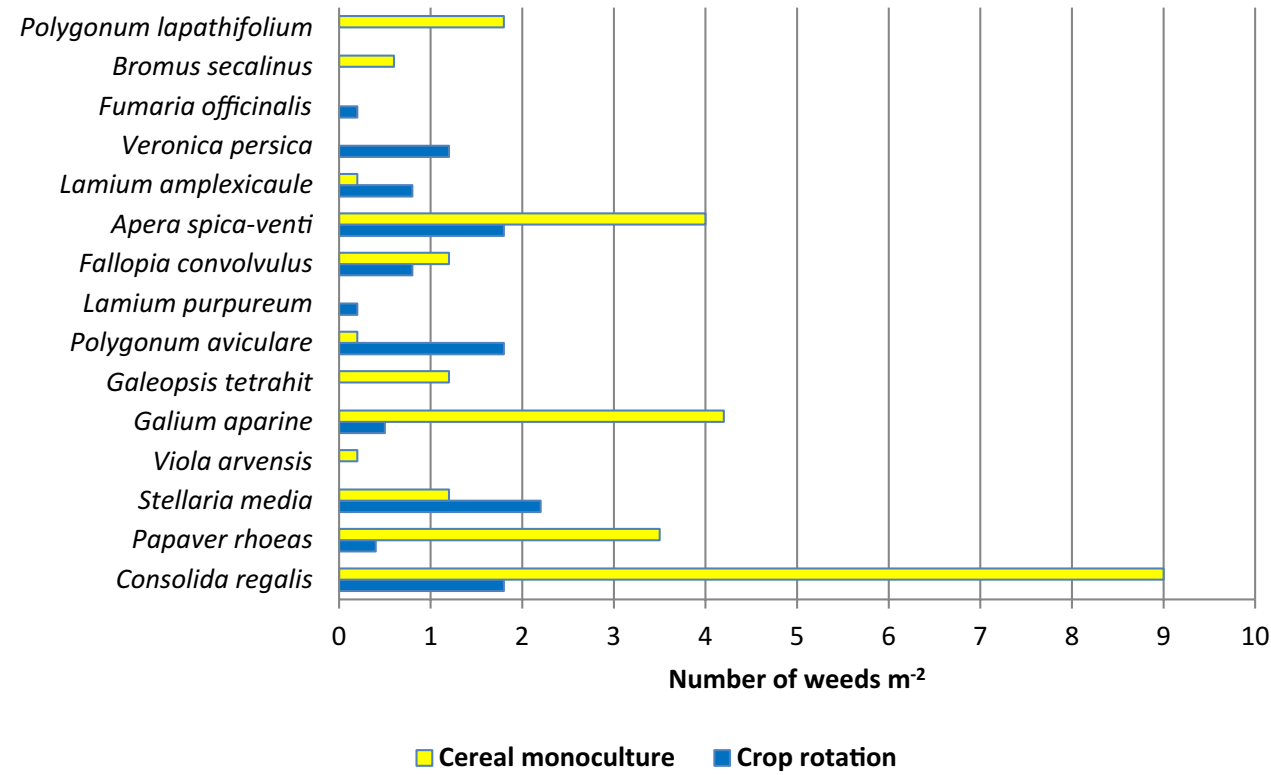

Table 7 Chemical properties of soil and number of earthworms (in $0-30 \mathrm{~cm}$ soil layer)

\begin{tabular}{|c|c|c|c|c|}
\hline \multirow[t]{2}{*}{ Specification } & \multicolumn{2}{|c|}{ Cropping system } & \multicolumn{2}{|c|}{ Value } \\
\hline & $\mathrm{CR}$ & $\mathrm{CM}$ & $F$ & $P$ \\
\hline Organic $\mathrm{C}\left(\mathrm{g} \mathrm{kg}^{-1} \mathrm{dm}\right)$ & 16.3 & 10.9 & 58.3 & $* *$ \\
\hline Total $\mathrm{N}\left(\mathrm{g} \mathrm{kg}^{-1} \mathrm{dm}\right)$ & 0.89 & 0.74 & 31.2 & $*$ \\
\hline Number of earthworms $\mathrm{m}^{-2}$ & 29.0 & 20.0 & 41.4 & $*$ \\
\hline
\end{tabular}

$C R$ crop rotation, $C M$ cereal monoculture

$* P<0.05, * * P<0.01$

matter facilitates earthworm number, whereas according to Crow et al. (2009) the presence of earthworms increases organic $\mathrm{C}$ content in the soil and its bioactivity (Kretzschmar and Monestiez 1992).

Cereals sown in the monoculture are inseparably accompanied by weeds having a similar developmental cycle (Woźniak and Soroka 2015). Their eradication requires using herbicides with a different mechanism of action and belonging to various chemical groups (Mal et al. 2015; Mehmeti et al. 2018). Alternate cultivation of winter and spring cereals is recommended under such conditions, as it may prevent or even eliminate the prevalence of many weed species (Woźniak and Soroka 2015).

\section{Conclusions}

The yield of winter wheat cultivated in the CM system was significantly lower compared to the winter wheat grown in the CR system. Its grain yield reduction was due to a lower number of spikes $\mathrm{m}^{-2}$, lower 1000 grain weight, and lower grain weight per spike, than in the CR system. Wheat grain harvested from the CM system was characterized by a lower content of wet gluten, lesser grain volume weight and grain uniformity, and contained more total ash than the grain harvested from the CR system. The number and air-dry weight of weeds were higher in the CM than in the CR system. Differences were also demonstrated between both systems in the species composition of weeds. Soil samples collected from the $\mathrm{CM}$ plots contained less organic $\mathrm{C}$ and total $\mathrm{N}$ than these from the CR system. This soil had also a lower number of earthworms compared to the CR soil.

Open Access This article is distributed under the terms of the Creative Commons Attribution 4.0 International License (http://creativecommons.org/licenses/by/4.0/), which permits unrestricted use, distribution, and reproduction in any medium, provided you give appropriate credit to the original author(s) and the source, provide a link to the Creative Commons license, and indicate if changes were made.

\section{References}

Bai, G., \& Shaner, G. (2004). Management and resistance in wheat and barley to Fusarium head blight. Annual Review of Phytopathology, 42, 135-161.

Balota, E. L., Kanashiro, M., Filho, A. C., Andrade, D. S., \& Dick, R. P. (2004). Soil enzyme activities under long-term tillage and crop rotation systems in subtropical agroecosystems. Brazilian Journal of Microbiology, 35, 300-306.

BBCH Working Group. (2001). Growth stages of mono-and dicotyledonous plants. In U. Meier (Ed.), Federal Biological Research Centre for Agriculture and Forestry (2nd ed).

Beres, B. L., Harker, K. N., Clayton, G. W., Bremer, E., Blackshaw, R. E., \& Graf, R. J. (2010). Weed-competitive ability of spring and winter cereals in the Northern Great Plains. Weed Technology, $24,108-116$. 
Bruyn, L. A. L., \& de Kingston, T. J. (1997). Effects of summer irrigation and trampling in dairy pastures on soil physical properties and earthworm number and species composition. Australian Journal of Agricultural Research, 48, 1059-1079.

Cattaneo, F., Di Gennaro, P., Barbanti, L., Giovannini, C., Labra, M., Moreno, B., et al. (2014). Perennial energy cropping systems affect soil enzyme activities and bacterial community structure in a South European agricultural area. Applied Soil Ecology, 84, 213-222.

Clapperton, M. J., Lee, N. O., Binet, F., \& Conner, R. L. (2001). Earthworms indirectly reduce the effects of take-all (Gaeumannomyces graminis var. Tritici) on soft white spring wheat (Triticum aestivum cv. Fielder). Soil Biology \& Biochemistry, 33, 1531-1538.

Crow, S. E., Filley, T. R., McCormick, M., Szlavecz, K., Stott, D. E., Gamblin, D., et al. (2009). Earthworms, stand age, and species composition interact to influence particulate organic matter chemistry during forest succession. Biogeochemistry, 92, 61-82.

Debaeke, P., Aussenac, T., Fabre, J. L., Hilaire, A., Pujol, B., \& Thuries, L. (1996). Grain nitrogen content of winter bread wheat (Triticum aestivum L.) as related to crop management and to the previous crop. European Journal of Agronomy, 5, 273-286.

Emmerling, C. (2007). Reduced and conservation tillage effects on soil ecological properties in an organic farming system. Biological Agriculture \& Horticulture, 24, 363-377.

Haliniarz, M., Nowak, A., Woźniak, A., Sekutowski, T. R., \& Kwiatkowski, C. A. (2018). Production and economic effects of environmentally friendly spring wheat production technology. Polish Journal of Environmental Studies, 27, 1523-1532.

IUSS Working Group WRB. (2015). World Reference Base for Soil Resources 2014, update 2015. International soil classification system for naming soils and creating legends for soil maps. In World Soil Resources Reports No. 106. FAO, Rome.

Kretzschmar, A., \& Monestiez, P. (1992). Physical control of soil biological activity due endogenic earthworm behaviour. Soil Biology \& Biochemistry, 24, 1609-1614.

Lal, R. (2016). Soil health and carbon management. Food and Energy Security, 5, 212-222.

Laossi, K. R., Ginot, A., Noguera, D. C., Blouin, M., \& Barot, S. (2010). Earthworm effects on plant growth do not necessarily decrease with soil fertility. Plant and Soil, 328, 109-118.

Lund, M. G. (1993). Tillage and crop rotation affect corn, soybean, and winter wheat yields. Journal of Production Agriculture, 6 , 207-213.

Mal, P., Schmitz, M., \& Hesse, J. W. (2015). Economic and environmental effects of conservation tillage with glyphosate use: A case study of Germany. Outlooks on Pest Management, 26, 24-27.

Mehmeti, A., Pacanoski, Z., Fetahaj, R., Kika, A., \& Kabashi, B. (2018). Weed control in wheat with post-emergence herbicides. Bulgarian Journal of Agricultural Science, 24, 74-79.
Nikolich, L., Milosev, D., Seremesich, S., Dalovich, I., \& Vuga-Janjatov, V. (2012). Diversity of weed flora in wheat depending on crop rotation and fertilisation. Bulgarian Journal of Agricultural Science, 18, 608-615.

Olsson, S., \& Alström, S. (2000). Characterisation of bacteria in soils under barley monoculture and crop rotation. Soil Biology \& Biochemistry, 32, 1443-1451.

Rachoń, L., Szumiło, G., Brodowska, M., \& Woźniak, A. (2015). Nutritional value and mineral composition of grain of selected wheat species depending on the intensity of a production technology. Journal of Elementology, 20, 705-715.

Ranjbar, A., Sepaskhah, A. R., \& Emadi, S. (2015). Relationships between wheat yield, yield components and physico-chemical properties of soil under rain-fed conditions. International Journal of Plant Production, 9, 433-466.

Rasmussen, I. A., Askegaard, M., Olesen, J. E., \& Kristensen, K. (2006). Effects on weeds of management in newly converted organic crop rotations in Denmark. Agriculture, Ecosystems \& Environment, 113, 184-195.

Roche, E. H., Mallory, E. B., Molloy, T., \& Kersbergen, R. J. (2017). Evaluating organic bread wheat as a rotation crop for organic dairy farms. Renewable Agriculture and Food Systems, 33, 163-178.

Schlegel, A. J., Assefa, Y., Haag, L. A., Thompson, C. R., \& Stone, L. R. (2018). Long-term tillage on yield and water use of grain sorghum and winter wheat. Agronomy Journal, 110, 269-280.

Soane, B. D., Ball, B. C., Arvidsson, J., Basch, G., Moreno, F., \& Roger-Estrade, J. (2012). No-till in northern, western and southwestern Europe: A review of problems and opportunities for crop production and the environment. Soil and Tillage Research, 118, $66-87$.

Woźniak, A., \& Kawecka-Radomska, M. (2016). Crop management effect on chemical and biological properties of soil. International Journal of Plant Production, 10, 391-401.

Woźniak, A., \& Makarski, B. (2013). Content of minerals, total protein and wet gluten in grain of spring wheat depending on cropping systems. Journal of Elementology, 18, 297-305.

Woźniak, A., \& Soroka, M. (2015). Structure of weed communities occurring in crop rotation and monoculture of cereals. International Journal of Plant Production, 9, 487-506.

Woźniak, A., \& Soroka, M. (2017). Effect of tillage systems on weed infestation of durum wheat. International Journal of Plant Production, 11, 435-460.

Woźniak, A., \& Soroka, M. (2018). Effect of crop rotation and tillage system on the weed infestation and yield of spring wheat and on soil properties. Applied Ecology and Environmental Research, 16, 3087-3096. 